\title{
6-phosphogluconate dehydrogenase deficiency
}

INSERM

\section{Source}

INSERM. (1999). Orphanet: an online rare disease and orphan drug data base. $\underline{6-}$ phosphogluconate dehydrogenase deficiency. ORPHA:99135

A rare constitutional hemolytic anemia characterized by a low 6 -phosphogluconate dehydrogenase activity in the erythrocytes, which clinically manifests with a wellcompensated chronic nonspherocytic hemolytic anemia and transient hemolytic periods with jaundice. 